\title{
Economic Contribution of Forest Resource at Household Level in the Bale Mountains Eco-Region Redd+Project, Southern Ethiopia
}

\author{
Adamu Debelo Fetensa ${ }^{1} \quad$ Mustefa Sultan Dalu ${ }^{2} \quad$ Tadese Bedada $^{3}$ \\ 1.Department of Economics, Faculty of Business and Economics, Ambo University, Ambo, Ethiopia \\ 2.Department of Forestry, College of Agriculture and Environmental Science, Arsi University, Assela, Ethiopia \\ 3.Oromia Urban planning Institute, Addis Abeba, Ethiopia
}

\begin{abstract}
Forest significantly contributes to household incomes and influences patterns of economic development by promoting sustainable or green development. Yet, effective forest use and management/governance requires a deeper understanding of forest's multiple socio-economic functions or benefits at various scales, in particular at local level. Hence, reliable and up to-date information on the state of forest resources - not only on area and area change, but also on such variables as economic contribution for household environment and others variables are very important. This study was conducted in Southern Ethiopia in the Oromia region in the district of Dodola. The main objective of the study was to assess the economic contribution of forest resource at household level. Data were collected through household survey, group discussions and key informant interviews. Data was analysed by statistical methods include descriptive statistics, Leaner regression analysis. The results of the study show that forest products are important sources of income contributing to $30 \%$ and $51.3 \%$ of household per capita income and per capita cash income, respectively. Forest income is an important bumper against extreme poverty by filling seasonal gaps of income and by serving as safety net in times of income crisis. Forest income also provides the opportunity to diversify livelihoods, particularly for low income groups. Households' decisions on livelihood strategies including dependence on forest income are associated with socioeconomic and geographical factors. It is recommended that a better outcome in terms of poverty alleviation can be achieved if pro-poor forest-based activities are specifically considered in planning conservation and development interventions.
\end{abstract}

Keywords/Phrases: Bale Eco Region, Forest income, forest-management at household level, Oromia, Ethiopia, REDD+

DOI: $10.7176 / \mathrm{JRDM} / 53-02$

Publication date:March $31^{\text {st }} 2019$

\section{INTRODUCTION}

\section{Back Ground}

Humans have depended on forests for a remarkable variety of products, services, and benefit. Historically, forests have played a major role to influence patterns of economic development, supporting livelihoods, helping structure economic change, and promoting sustainable growth.

For millennia before the industrial revolution, forests, woodland, and trees were the source of land for cultivation and settlement, of construction materials, of fuel and energy, and indeed of food and nutrition as well (Williams 2002).

Forests continue today to provide the high levels of commercial benefits to households, companies, and governments that formed the initial impetus for protective statutes and policies.

The FAO estimates that forest industries contribute more than US $\$ 450$ billion to national incomes, contributing nearly 1 percent of the global GDP in 2007 and providing formal employment to $0.4 \%$ of the global labor force (FAO 2008). Forests contribute extremely to the global energy supply as well as providing food, fodder, medicines, building materials, and paper products etc. Furthermore, forests have cultural, spiritual and recreational values. They are also vital for climate mitigation and soil and water protection (FAO, 2008).

Globally more than 1.6 billion people rely on forest resources for their livelihoods (Food and Agriculture Organization [FAO, 2006]). About $50 \%$ of the total rural residents worldwide communities live in extreme poverty (World Bank, 2011) People in extreme poverty. These people lack the basic necessities to maintain a decent standard of living such as sufficient and nutritious food, adequate shelter, and access to health services, energy sources, and safe drinking water. Forests are sources of financial incomes and resources for subsistence and to cope with unforeseen shocks to household incomes particularly for the rural poor (Chomitz and Kumari 1998).

In addition to local communities, forests continue to benefit private companies, and governments that formed the initial impetus for protective statutes and policies. Economic forces are tied intimately to the status of forests. While forest resources form, an important input into economic production and consumption activities, at local, national and global levels, economic activities can also contribute to forest degradation. Economic forces comprise both the direct and the underlying causes of forest loss.

Activities such as resource over-exploitation, the use of damaging or destructive harvesting methods, and the clearance of forestlands for agriculture all degrade and deplete forests directly. An important aspect of community- 
based approaches to forest management is whether they attempt to offset these direct causes of forest degradation and loss.

Forestry can also play significant role in boosting economic development of agrarian countries like Ethiopia. However, the contribution of forestry sector to the country's GDP in promoting the whole economy as compared to agriculture sector has been very low $(5.5 \%)$ due to policy failure and market imperfection resulting from lack of measurement and valuation of the non-marketable goods and services obtained from forest resources ( Tesfaye et al.2011).

More recent shifts in thinking about forests and the benefits they provide have used the lens of ecosystem services. Many researchers and decision makers recognize the important role of economic incentives from local to national levels in reducing deforestation. They argue for the need to compensate producers of forest ecosystem services. The possibility of mitigating climate change through terrestrial carbon sequestration in forest areas has thus led to the development of new regulatory and economic strategies to protect and improve forest cover through payments for ecosystem services in programs such as REDD+ (UNFCCC, 2013).

REDD + created elevated many expectations at various scales. Local communities, politicians, governments and NGOs are hoping that modest carbon finance might be established to offset parts of the greenhouse gases (GHGs) from the atmosphere as well as mitigate the emissions. Failure to establish carbon finance mechanism and meet the expectations may cause REDD+ to "s collapse in the future (Haile Mariam et al.2015).

The level of benefits and costs that accrue to communities from managing forests sustainably is a major economic concern. One of the primary reasons that forests are degraded is because communities can gain substantial financial profits and economic benefits from carrying out economic activities in ways, and at levels, that clear forestland or deplete forest resources. People carry out these unsustainable economic activities to generate subsistence and income, because in the short run they often yield higher returns than the income and subsistence benefits accruing from sustainable forest management.

\section{Statement of the Problem}

Forest resources are valued more for the supply of household energy while other roles in the economy of rural households are not fully respected. Moreover, the relative importance of these forest functions is always changing due to changing level of awareness and attitudes towards natural resources. Thus, the challenge for forest contribution income and environmental governance is to make decisions about options and choices, align these options to the inherent values and needs of society and implement them effectively through capable institutions and relevant practices (Sampford, 2002). Besides, the differentiated roles of forest contribution products in the economy of rural households are not fully appreciated. Income from forest resources are not properly valued and are usually lumped in a non-farm income category (SDPRP, 2002). However, the importance of forest resources in the income portfolio and their role in the economic contribution strategies of rural household have been indicated in some small scale local studies (Dercon and Krishnan, 1996, Mamo et al., 2007, Tefera et al., 2004). The description of major economic contribution of forest for household value does not portray links with the natural resource component, particularly forest resources, despite the major role of forests as energy sources.

In addition, the forests have the potential to make a major contribution to national economic development by meeting basic needs in wood energy, non-timber forest products, environmental services, industrial wood and pulp and paper products. However, it is under-estimated, or no accurate data of the contribution from different activities to employment are of similar proportions. The actual forest contribution is estimated to be much higher than what is captured in economic data at present. Thus the study was attempt to reduce the gap by providing estimates from field data collects in Dodola district particularly in Daneba and Berisa kebele in the zone.

The most likely significant contribution from the forestry sector is that of providing goods and services, shelter, food, safety nets and buffers against the hardships of small householder producers. The rural small-scale farmers also rely on forests to provide biomass.

The purpose of this study is to provide empirically supported information that can contribute to a better understanding of the estimation socioeconomic contribution of forest economy for individual household and enhance the formation of effective institutional arrangements towards achieving successful economic contribution. The study is undertaken against the framework of economic contribution of forest that has been limit household economy.

The study was attempted to zoom in on and describe the salient features of the actual implementation of the estimation contribution of forest economy and the perspective of the local people involved in the arrangement. It explains the patterns of forest use, the place of forest production in the economic strategy of rural households, the differentiation of dependence on the forest and income among households, and the function of forest income in households risk management strategy and poverty alleviation.

Communities organized into PFM cooperatives are devoting their labor and time to forest management. However, there is no evidence on how much the local communities are compensated from the benefits they are driving from the forest. Thus, this study is proposed to acquire scientific evidence on economic contribution 
of forest resource to a household income.

\section{Significance of the Study}

The Bale Eco-region forest resource contributes to household economy in various ways. In this study, the estimation of economic contributions include fuel woods, house construction, charcoal, cattle grazing and others. However this research was reduce the gap of the other studies and compressive studies that exactly quantify the contribution of forest resources to household economy.

Forests have multiple socio-economic functions benefits at the global, national and local scales, and play a vital part in sustainable development. Hence, reliable and up to-date information on the state of forest resources not only on area and area change, but also on such variables as economic contribution for household environment and others variables are very important.

REDD + is a policy mechanism aimed at not only reducing carbon dioxide emissions from developing countries through sustainable management of forests, but also at providing co-benefits in terms of biodiversity and livelihoods (UNFCCC, 2010). In principle, therefore, REDD+ is meant to slow (or even reverse) the rate of forest loss and degradation in developing countries, while at the same time providing socioeconomic benefits to communities or at worst not causing unjustified harm to their well-being.

Nonetheless, little has been published on existing efforts to involve local stakeholders in REDD+ implementations and or on how community-based REDD+ implementation plays out in practice, including issues of community-level to estimate economic contribution of forest for the household level.

\section{Scope and Limitations of the Study}

The scope of this thesis limited to examining the economic contribution of forest resource to household economy to understand the extent to which different income groups depend on forest REDD+ initiative in the Bale mountain eco-region. The study is restricted only to one district of the eco-region, that is Dodola district. Within this district, the study covered two kebeles, namely Berisa and Deneba. Due to resource constraint, the study was covered only a limited number of farmers who were sampled from the two kebeles. These two kebeles are believed to be good representative of the district, because Dodola has "dega" agro-ecological zone and have importance with similar social, economic, and institutional set ups. In addition, most of the respondent's data limited on conditional time data and this may not be enough to generate adequate information because there may be many variables, which could potentially be changed from one survey time to another survey time within a given locality based on the type of survey used and other reasons. Besides, as this thesis used regression analysis method to measure individual welfare, all limitations associated with the theory are here.

\section{METHODOLOGY}

Description of the Study Area

Location, climate, population and brief history of study area.

The Bale Mountains Eco-region lies between $5^{\circ} 22^{\prime}-8^{\circ} 08^{\prime} \mathrm{N}$ and $38^{\circ} 41^{\prime}-40^{\circ} 44^{\prime} \mathrm{E}$ within the Oromia Regional State in the Southern Ethiopia. Among the Bale Mountains Eco-region Adaba-Dodola is found the northern foothills of the Bale Mountains (between 6050'-7000'N la and 39007'-39022'E lo (Teshome, 1999). The Bale Mountains Eco-region is one of the two highland divisions in Ethiopia, separated from the larger called western plateau of the Ethiopian highlands by the Great African Rift Valley, one of the longest and most profound chasms in Africa and the world. The main central area of the Bale Eco-region is a high plateau, much of which is over $3000 \mathrm{~m}$ a.s.l. with several peaks rising from it. The highest peak in the eco-region is Tullu Dimtu $(4377 \mathrm{~m})$, the second highest point in Ethiopia. South of the plateau the land falls steeply to the Harenna Escarpment and further into the Somali and Borana lowland plains, and further into the Indian Ocean.

Administratively, the project area comprises sixteen Districts namely Agarfa, Dinsho, Adaba, Dodola, Goba, Sinana, Gololcha, Gasera, DeloMena, Kokosa, Berbere, Harenna Buluk, Nensebo, Mada Walabu, Goro and Guradhamole. In these districts there are six priority forest areas (PFAs): Aloshe Batu, Goro Bale, Harana Kokosa, Menna Angetu, Kubayu, and Adaba Dodola, which in total are 566,258 ha including the forests in the Bale Mountains National Park or 480,910 ha without the park forests. The total population of the districts is more than 1.6 million, $85 \%$ of which is rural and the rest urban. Dodola has a total of 237,805 residents (population) with a crude population density of 42 per square kilometer.

Farm Africa and SoS Sahel-Ethiopia have worked in the Bale Eco-region since 2006, addressing deforestation by developing and pioneering a Participatory Forest Management (PFM) approach and a REDD+ scheme. Up to date 100 CBOs established to manage and use the forest resources sustainably. About 64 of the established CBOs are selected as REDD+ CBOs. Anthropogenic deforestation is one of the major environmental problems in Bale Eco-region: between 2000 and 2011 alone, the Eco-region experienced an average annual deforestation rate of $2.6 \%$ and lost 178,000 ha of high forest. During this period, it caused emissions of $70 \mathrm{Mt} \mathrm{CO2e} \mathrm{GHG} \mathrm{and} \mathrm{had} \mathrm{a}$ significant detrimental environmental impact on biodiversity and livelihood opportunities (OFWE, 2014). 
A bimodal local climate with two wet seasons that have heavy and small rains is characteristic in the eastern part of the project area, while the western part is characterized by a mono-modal rainfall pattern. In the part with a bimodal rainfall pattern, heavy rain occurs from July to October, with the highest peak in August and the small rains from March to June, with a peak in April. There are typically eight rainy months (March-October) and four dry months (November-February) in a given year in the part with mono-modal patter. The far south and lower altitudinal areas experience a shorter, four-month rainy season usually from February to June. This lower altitude area receives between $600-1000 \mathrm{~mm}$ of rainfall annually, whereas the higher altitudinal areas receive between $1000-1400 \mathrm{~mm}$. The mean annual temperature of Bale-Eco region and Dodola district are $14^{\circ} \mathrm{C}$ and $16^{\circ} \mathrm{C}$ respectively.

The daily temperatures during the dry season show high fluctuation. The lowest temperature that has been recorded in the mountains is $-150^{\circ} \mathrm{C}$ at night, with the highest recorded temperature the next day of $+260^{\circ} \mathrm{C}$; thus a range of $400^{\circ} \mathrm{C}$ within a 24-hour period.The vegetation ecosystems of the Bale Eco-Region include: Afro-alpine grassland, Erica forest/shrubland, Mountain grassland, Dry Afromontane evergreen forest, Moist Afromontane evergreen forest, Bamboo forest, Combretum-Terminalia woodland, Acacia-Commiphora woodland and Wetland. The fauna and flora species in the eco-region comprise a large percentage of Ethiopia's endemics, some species of which are only found in Bale.

The main soil types common in the area are Cambisols, Vertisols, Luvisols, Lithosols and Nitosols. There is limited information on the conditions of the soils of the eco-region due to limited study on soils of the area. However, the Vertisols, Cambisols and Luvisols in the wide plateau of the eco-region are very fertile supporting subsistent and commercial agriculture with high productivity to the standard of the country.

Specifically Dodola is one of Bale mountain Eco region found in the Oromia national regional state (ONRS) of Ethiopia in the West Arsi Zone administrative area in the Dodola district (district) (Figure 2). It has a total area of $356,006 \mathrm{~km} 2$ constituting $35 \%$ of the total population and $31 \%$ of the total area of the country (CSA, 2008). About $12.4 \%$ of the population lives in urban areas. The forest area is situated in the Bale Mountains eco-region. The Bale Mountains eco-region is known for its extensive area of Afro-alpine, as the origin of four major rivers, which are the only sources of perennial water for the arid lowlands of the east and southeast of Ethiopia, and for its unique and diverse fauna and flora (CRSO-BARD). It is the location of the Bale Mountains National Park and several forest priority areas (ibid). The climate of Bale ranges from tropical in the southeaster lowlands to alpine in the north-western highlands, the altitude varying between 400 and $4377 \mathrm{~m}$ a.s.l. (GFA, 1991).

The total population of the district is about 194,000. The urban population of $35,000(18 \%)$ is one of the largest in the zone (CSA, 2008). An early estimate indicated that $95 \%$ percent of the total population belongs to the Oromo ethnic group and the remaining 5\% constituted mainly of the Amhara and Guraghe ethnic groups (GFA, 1991). Based on the households sampled in the survey, almost all households are from Oromo ethnic groups. For the Dodola area, June, July and August constitute the growing season when the cultivation, seeding, fertilizing and weeding activities take place. September is the month with a relatively low level of agricultural work. Harvesting starts in October for barley, November for teff, and between November and December for wheat. About $60 \%$ of the rainfall comes in the main rainy season from June to August while a small amount of rainfall occurs between January and March followed by a dry spell in May. The main dry season is in November and December (IFMP, 1999).

The daily temperature varies between $14^{\circ} \mathrm{C}$ and $17^{\circ} \mathrm{C}$ at an altitude of $2500 \mathrm{~m}$ (ibid). A daily temperature variation between $8^{\circ} \mathrm{C}$ and $27^{\circ} \mathrm{C}$ has been recorded for the years $1996-2002$.

Table 1: Dodola district WAJIB with their members

\begin{tabular}{|l|l|l|l|l|}
\hline \multirow{2}{*}{ No } & \multirow{2}{*}{ CBO Name } & \multicolumn{3}{|c|}{ Members } \\
\cline { 3 - 5 } & & Male & Female & Total \\
\hline 1 & Adele & 238 & 76 & 324 \\
\hline 2 & Ashena Robi & 94 & 26 & 120 \\
\hline 3 & Dobedo Kuse & 86 & 202 & 288 \\
\hline 4 & Hara Bubiftu & 200 & 88 & 288 \\
\hline 5 & Mekalitu Ode & 168 & 30 & 198 \\
\hline 6 & Bura Chele & 206 & 48 & 254 \\
\hline 7 & Burkitu Bikika & 168 & 32 & 200 \\
\hline 8 & Berisa & 135 & 28 & 163 \\
\hline 9 & Deneba & 347 & 115 & 462 \\
\hline
\end{tabular}

Source: Survey data (2016) REDD+ field office. 


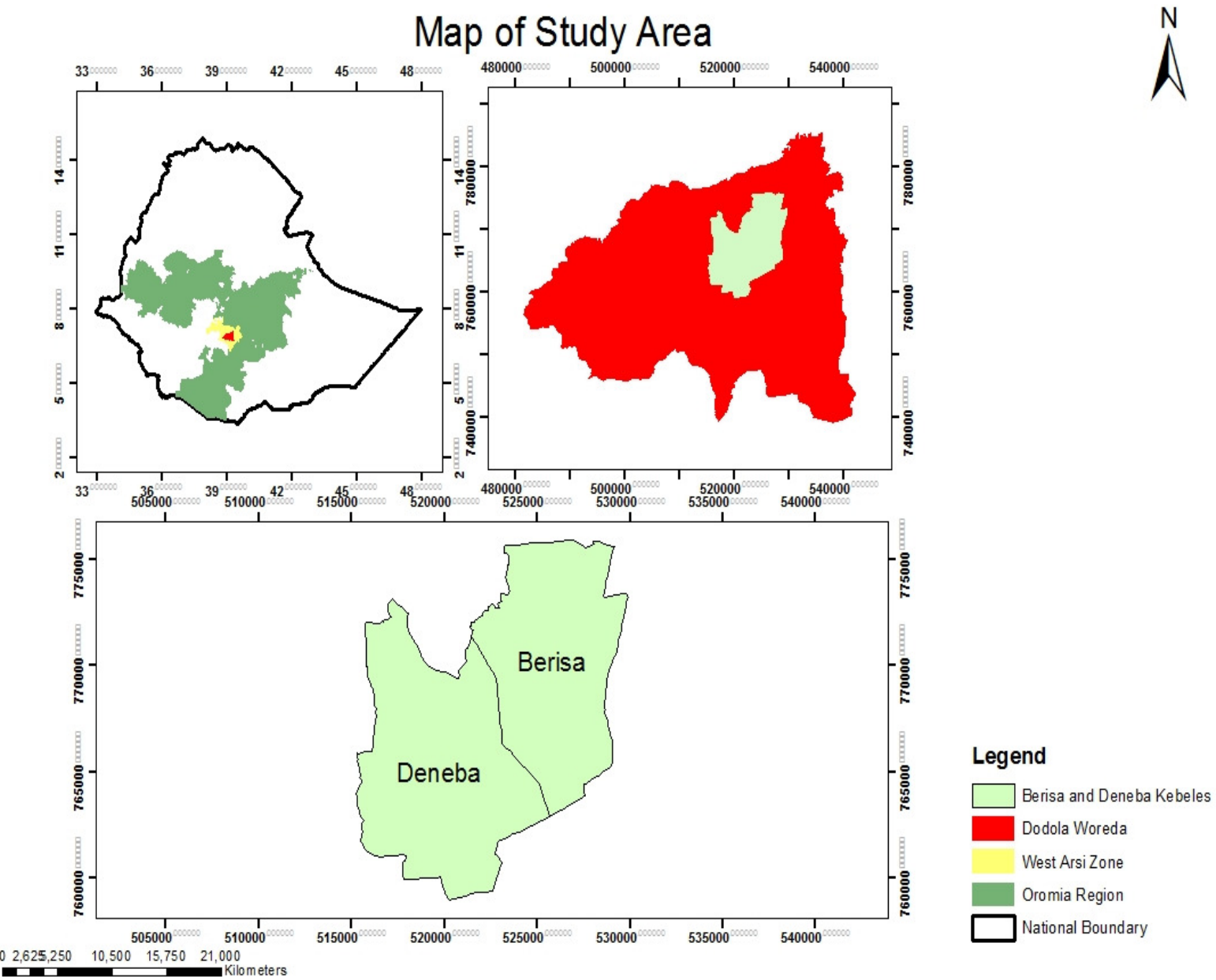

Figure 1: Geographical location of the study area

\section{Sampling Design and Procedures}

Bale REDD+ is being implemented in 11 districts of Bale eco-region. Among 11 Bale REDD+ phase project intervention districts, only one district has been randomly selected. That is Dodola, district which has 9, REDD+ CBOs. From these 9 REDD + CBOs, 2 REDD + CBOs namely Deneba and Berisa were randomly selected. For this study, a 153 sample households were selected based on the sample size of population in the study area or. To select sample of household simple random sampling method was employed. In-person interviews are generally believed to produce the better data, though they are very expensive to undertake. Secondary data desirable was taken from Bale REDD+ field office and data was taken from different individuals as secondary source

\section{Sampling}

Data for the empirical study were drawn from, closed formal questionnaire designed for gathering relevant quantitative and qualitative data from respondents. The reason for choosing those two PAs among the 9 of CBO was their pioneering role in concluding contracts with the forest administration implementing the WAJIB approach. WAJIB blocks were stratified into groups based on strata neighbours and selection of blocks was made randomly from each strata. Two separate lists of kebeles, one from Deneba and other from Berisa, were compiled (Table 1). The member of households in each WAJIB members was as shown compiled.in (Table 2).Deneba PA includes those WAJIBs that are located at the forest-agriculture frontier. Owing to their location and relative accessibility, most of the forests in these WAJIBs have been exposed to massive exploitation before WAJIB establishment.

The Berissa PA consists of the oldest WAJIBs. The new concept of forest dwellerse association was first accepted in the Berissa peasant association. Most of the WAJIB"s in the Berissa PA are also found at the forest frontier and close to the main road. Thus, there has been massive exploitation before the establishment of WAJIBs. Because this areas the nearest marketplace is the Dodola market place or twon. 
Table 2: The number of samples taken from WAJIB blocks in the studied kebeles.

\begin{tabular}{|c|c|c|c|c|c|}
\hline S.N & Kebeles & WAJIB block & Number of Respondents & Male & Female \\
\hline \multirow[t]{7}{*}{1} & Berisa & Gede & 7 & 6 & 1 \\
\hline & & Mudi & 6 & 6 & 0 \\
\hline & & Sokora & 6 & 4 & 2 \\
\hline & & Ali & 7 & 6 & 1 \\
\hline & & Sulala & 6 & 4 & 2 \\
\hline & & Bulchano & 7 & 6 & 2 \\
\hline & Sub-total of Berisa kebele & & 40 & 32 & 8 \\
\hline \multirow[t]{17}{*}{2} & Deneba & Bulchana Hubo & 7 & 6 & 1 \\
\hline & & Cangeti & 7 & 5 & 2 \\
\hline & & Ido Sibilo & 8 & 6 & 2 \\
\hline & & Jeldo Bubisa & 7 & 5 & 2 \\
\hline & & Ido Wite & 7 & 6 & 1 \\
\hline & & Tarura & 8 & 6 & 2 \\
\hline & & Deneba Hida Tula & 8 & 4 & 3 \\
\hline & & Shushi Shika & 8 & 6 & 2 \\
\hline & & Birbirsa Guta & 8 & 6 & 2 \\
\hline & & Botole Changiti & 7 & 5 & 2 \\
\hline & & Sadi Oda & 8 & 5 & 2 \\
\hline & & Lobe Gutu & 8 & 6 & 2 \\
\hline & & Lephepho Dugda Guda & 8 & 5 & 3 \\
\hline & & Artu Fite & 7 & 6 & 1 \\
\hline & & Anunu Lobe & 7 & 6 & 1 \\
\hline & Sub-total of Denebekebele & & 113 & 83 & 28 \\
\hline & \multicolumn{2}{|l|}{ Grand total } & 153 & 115 & 36 \\
\hline
\end{tabular}

Table 3: Number of the Household Members in CBOs in the studied areas

\begin{tabular}{|l|l|l|l|}
\hline Kebele & $\begin{array}{l}\text { Number of the interviewed } \\
\text { households }\end{array}$ & $\begin{array}{l}\text { Number of the non- } \\
\text { interviewed households } \\
\text { householdsHousehold }\end{array}$ & Total number of households \\
\hline Deneba & 113 & 352 & 462 \\
\hline Berisa & 39 & 124 & 163 \\
\hline
\end{tabular}

Source: Survey data (2018)

This is because based on the total number of households in the two kebeles, households would have been selected 113 from Deneba (with a total of 462 households members) and 39 from Berisa (which had only 163 households members) if proportional sampling had been used (Table 3 ).

Thus, the study also aimed to get an even distribution of households across the two kebeles. The average number of $\mathrm{CBO}$ groups in the two areas was sampled 153 sample size $74 \%$ was taken from Deneba and $26 \%$ from Berisa from total number of $\mathrm{HH}$ based on the member ship size frame of the WAJIB members. Among the $74 \%$ and $26 \%$ of interviewed household members $20 \%$ and $5 \%$ is a numbers of females households interviewed from the $\mathrm{CBO}$ in Deneba and Berisa respectively. In other meaning from the $74 \%$ and $26 \%$ interviewed household $19 \%$ and $5 \%$ interviewed is the number of female in Deneba and Berisa respectively.

Table 4: sample size determination mechanism

\begin{tabular}{|c|c|c|c|c|c|c|c|}
\hline \multicolumn{7}{|c|}{ Determining sample size to study Opportunities and Challenges to Establishe } & \multirow{3}{*}{\begin{tabular}{|l|} 
community sampled $\mathrm{HH}$ \\
$\begin{array}{l}\text { Proportionally distributed } \\
\text { sample size }\end{array}$
\end{tabular}} \\
\hline \multirow[t]{2}{*}{ Kebele } & \multirow[t]{2}{*}{ CBO Name } & \multicolumn{2}{|c|}{ CBO Members } & & \multirow{2}{*}{\multicolumn{2}{|c|}{ Sample size }} & \\
\hline & & Male & Female & Total & & & \\
\hline Deneba & Deneba & 347 & 115 & 462 & 153 & 113.0976 & 113 \\
\hline Berisa & Berisa & 135 & 28 & 163 & 153 & 39.9024 & 40 \\
\hline \multicolumn{2}{|c|}{ Grand Total } & & & 625 & & 153 & 153 \\
\hline
\end{tabular}

So, study sample size adiministered to 153 farmers using rule of thumb $\geq 50+8 \mathrm{~m}$; $\mathrm{m}=$ number of explanatory variak For this study $m=12 \quad 5 \%$ contingency taken above the minimum $=146+(.05 * 146)=153$ 
Members of households were defined as those households that were heavy forward the CBO members. Such households had one or more household member(s) who were involved in either decision making, needs assessment, resource mobilization and implementation activities. Contributing households were those who happily involved in doing different activities without payment or direct compensation. During the survey, sampled households were identified from the two lists of member's households with the help of two committee members, from each $\mathrm{CBO}$, who distinguished the households well.

\section{Data collection instrument}

Data used in this study were obtained from a questionnaire survey of 153 household heads from Deneba and Berisa communities. The questionnaire comprised mainly of structured questions in order to obtain qualified answers (Appendix 1). However, a few other questions were left open-ended to give interviewees a chance to express their views and draw lessons from their wisdom. The questionnaire was translated into the Regional language (Afaan Oromoo). It was then pre-tested, on three randomly selected households in Deneba and one randomly selected households in Berisa.

Following the pre-test, some questions were deleted and others modified to improve their clarity and ensure their contextual relevance. The questionnaire was subdivided into different sections.

There was brief introduction as to what is offered by REDD + and its expectations from households that are able to participate. The respondents were first asked if they are aware of REDD+ programme, what they are doing with REDD+ and the economic contribution of forest in households' economy. They were then asked if they were participating in the forest management and its costs. However, because there may be incentives to falsify data if the results are linked to financial flows (e.g., Nielsen and Lund 2012), strong third party verification was required. Cross-checks are provided by the government, and there is strong NGO and donor support. I am aware that openended questions usually create biases but I had tried to minimize this by reminding the respondents that they had to tell me the contribution of the forest products they are currently extracting. In this case, we expect the respondents to anchor their open-ended responses to their current forest income contribution for the household level.

\section{Primary Data Collection Methods \\ Field observation}

Observation would be done across visible WAJIB areas of Deneba and Berisa forest management area before conducting the main survey to understand estimation of forest income contribution processes ,production system, family members participating in forest management and also to observe age, sex ,time allocate to forest practice that have been adopted by local community in the area. Moreover, Informal discussion with local community would be done held for some general information of the topic.

\section{Questionnaire survey}

The questionnaire was prepared to collect information concerning households' background Information , forest income and estimation, forest management, income earn from forest Service, and main output of forest, respondent's perception on forest contribution and family member participating in activities, their cooperation in the role of GDP contribution of forest information etc. The questionnaire is prepared initially in English and translated into 'Regional 'language (Afaan Oromo). Enumerators would trained on the techniques of data collection and on the contents of the questionnaire, the questionnaire was pretested on randomly selected few households and the final survey was administered.

\section{Focus group discussion}

As people discuss the way they perceive things with each other, the possibility to reveal their true feeling and understanding about the topic can be increased. This is particularly important to have information people would otherwise like to cover. In addition, this method is used to have collective view of the respondents. A focus group discussion is invariably interested in the ways in which individuals discuses certain issues as a group, rather than simply as individuals.” (Bryman, 2008).

For such reasons, the researcher would conduct, at each survey site, three focus group discussions. The first team would made up of the CBO members, the second team would the community and REDD+ project staff and finally the third team would made up of the Leader of WAJIB. The size of the group varied from 5 to 10 people. As mentioned above, the main objective of the focus groups discussion would to give the researcher a broader understanding on how the community perceives the mission. Hence, the findings from the discussions would not present in the analysis and discussion part. The researcher would use the findings to triangulate data collected from the $\mathrm{CBO}$ member and the community via questionnaire and establish the relevancy of such data. 


\section{Key informant interview}

Key informant interview would be conducted with kebele managers and different officials, working in district Forest duelers and WAJIB forest management in Dodola district practice such as development agents, and zonal experts from the Agricultural and REDD+ Office.

\section{Secondary Data Collection Source}

In this study books, journals, articles, Reports, manuals, by browsing internet website and officially statistics collected from the offices at the local district had been used as secondary source of information.

\section{Methods of data Analysis}

Data was entered to SPSS version 20 statistical packages for analysis .The statistical methods include descriptive statistics, analysis of variance, and descriptive analysis. Descriptive statistics are important tools to present research results clearly and concisely. They help one to have a clear picture of the characteristics of sample units. Descriptive statistics aggregate household level data to user group attributes such as consistence sanction of illegal forest user, forest income and other attributes of user groups.

Additionally, analysis of variance to describe income classes in terms of socioeconomic characteristics, distribution of income among income sources, and the importance of forest products, as well as the leaner regression analysis to identify socioeconomic factors related to forest income and total income of households.

\section{Empirical Model and Estimation}

In this section, the forest income (output) function is derived from a short-run profit function. The profit function is estimated as a measure of welfare or benefit from harvesting products from local forests, and is used as a substitution measure of household welfare derived from commercial exploitation of local forest resources (Butry and Pattanayak, 2001). The profit function is in this context used to measure household dependency on local forests for cash income. Forest cash income is assumed to be increasing in forest income but decreasing in cost of forest extraction. The cost of harvest depends on a number of factors, but more directly on input prices, resource scarcity and a host of other market and institutional factors. The short-run profit function is modelled as a function of exogenous factors, which broadly embraces input and output prices and fixed socio-economic variables such as age, gender, marital status and education (Sadoulent and deJanvry, 1995). Inclusion of these socio-economic and institutional factors is justified by the prevalence of market imperfection and high transaction costs in peasant economies, cost of forest management (Pattanayak and Kramer, 1997). From the profit function, the forest income equation is derived as a function of not only input and output prices but also socio-economic and environmental factors such as forest condition and scarcity of forest products and services. These factors help us to identify the key determinants of household dependence on forest resources as a source of income. This framework does not impose strict profit maximizing behaviour on rural households because their decision to commercially exploit local forest resources for cash income is generally consistent with the standard behavioural assumptions that underlie utility and profit maximization. These assumptions include the need to have stable demand and supply functions. Factors that can influence household supply of forest products and forest income is broadly categorized into three. First, there are factors that are fixed to the household (land, cattle, labour etc). Second, those factors which cannot easily be varied in the short run mainly because they exhibit features of public goods such as forest services. Third, there are institutional factors that impose constraints on the household production function such as the nature of the forest management regime and access to input and output markets.

Labour is probably the single most important input in the harvesting of forest products, although capital inputs may also be important, especially in the harvesting of timber and construction poles and in charcoal production and marketing. Since inputs used in harvesting and collecting forest products are fixed in the short-run, the shortrun profit function can simple ben specified as follow as:

$\pi=$ Py- WI equation (1)

Where:

$\pi=$ is a vector of profit derived from harvesting forest products by a household,

$p=$ is a vector of prices of forest products harvested for sale,

$\mathrm{y}=\mathrm{is}$ a vector of outputs of forest products.

$\mathrm{w}=\mathrm{is}$ a vector of input prices and

$l=$ is a vector of input quantities.

So that profit can be considered in this study where $\pi=$ Income from forest and py $=$ where considered as $\mathrm{P}$ (wood, charcoal, construction materials, grazing, livelihood and etc., as well as W1 is labour land, Tools and etc. In this study profit is estimated by descriptive statistical analysis considering income from construction materials, from energy, as well as grazing .So that forest income contribution were measured by considering the above profit analysis by descriptive statistical ways.

Production and profit maximization is a function of available technology, which is assumed to be concave, 
continuous and at least twice differentiable, socio-economic variables (labour, age, gender, norms, beliefs, ethnicity, educational attainment etc.) and institutional factors (harvest rules, distance to markets, quality and abundance of forest resources etc.). Socio-economic and institutional variables are denoted by z. The household production function can now be specified as $y=f(1, z)$ and the input-demand and output supply functions respectively specified as a function of input prices (w), output prices (p) and socioeconomic and institutional factors $(\mathrm{z})$ as $\mathrm{l}=\mathrm{l}(\mathrm{p}, \mathrm{w}, \mathrm{z})$ and $\mathrm{y}=\mathrm{y}(\mathrm{p}, \mathrm{w}, \mathrm{z})$.

Substituting the input-demand and output-supply function into the short-run profit function above yields a new profit function expressed as a function of input prices, output prices and socioeconomic and institutional factors as follow as:

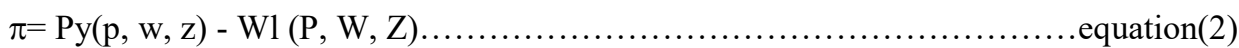

Taking first order conditions with respect to $\mathrm{w}$ and $\mathrm{p}$ yields the following optimal (profit-maximizing) input demand and supply functions

Furthermore, substituting into yields the maximum (optimal) profits that a typical household can earn by employing all its inputs efficiently for a given production technology. Equation shows that harvesting of forest products is a function of input prices (of labour and tools, etc), market prices of forest products, and fixed socioeconomic and institutional variables. Equation is the forest cash income equation, with inputs and output prices and socio-economic and institutional factors being its major determinants. The econometric model and estimation procedures are discussed below

Taking first order conditions with respect to $\mathrm{w}$ and $\mathrm{p}$ yields the following optimal (profit-maximizing) input demand and supply functions

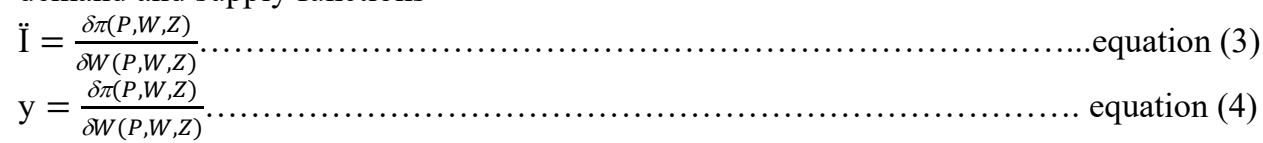

With the exception of protected forests (forest reserves), most forest resources in defenceless forests are harvested under open access conditions, and land for agriculture and settlement is generally abundant and is administered by customary authorities/leaders. Thus, the major constraints facing a typical rural household in the study area are scarcity of labour and labour augmenting inputs such as capital and raw materials. In this context, the amount of labour allocated to harvesting forest products for sale is expected to largely depend on factors that influence the net returns from forest gathering relative to competing uses of labour. Households combine their labour efforts with some capital (tools) or technology in order to increase production efficiency and lower transaction costs. Household endowments and socio-economic conditions are therefore expected to influence decisions on labour allocation and reliance on forest and woodland resources as sources of household income.

Access to markets and forest resources, spatial and temporal abundance of forest products, and relative prices of production inputs and outputs are expected to influence intra-household labour allocation decisions and consequently the quantity and value of forest products harvested for sale and for subsistence use.

The dependent variable, denotes forest income earned by the household, Y, is a set of explanatory variables, $\alpha$ and $\beta$ are parameters to be estimated, $\varepsilon$ is the random term and $i$ and $u$, indexes individuals and study sites respectively.

$\mathrm{Y}=\alpha \mathrm{iI}+$ age $+\beta 1$ gender $+\beta 3 \mathrm{HS}+\beta 4 \mathrm{MS}+\beta 5 \mathrm{EL}+\beta 6 \mathrm{ES}+\beta 7 \mathrm{REDD}+\mathrm{C}+\beta 8 \mathrm{FS}+\mathrm{WAJIB}$ rule $+\beta 10 \mathrm{DW}$ as source of revenue $+\beta 11 \mathrm{WAJIBm}+\beta 12 \mathrm{EH}+\varepsilon \mathrm{i}$

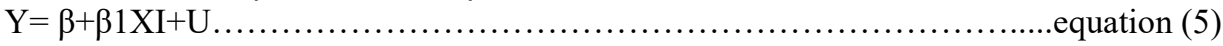

$\mathrm{Y}=$ is the dependent variable $\beta=$ are parameters to be estimated

$\mathrm{XI}=$ are explanatory variables $\mathrm{U}=$ indexes individuals

In this study only Leaner regression analysis were applied to explain econometric model based the following parameters.

Were $\mathrm{Y}=$ Forest income or dependent variable

$\mathrm{Xij},=$ explanatory variable. Therefore, that in this study there are twelve explanatory variables, which mentioned here.

The household's decision to harvest forest products also depends on geographical and temporal resource availability (Chidumayo and Mbata, 2002). Developing broad and accurate measures of scarcity/availability of multiple forest products harvested under open access conditions is often difficult, especially where data is largely unavailable or of poor quality. In this thesis, household qualitative ranking of forest resource abundance in open forests relative to better managed and resourced local forest reserves were compiled and used to compute a proxy measure of physical resource abundance.

Physical measures of resource scarcity often perform poorly as indicators of economic scarcity which is largely influenced by access to forest resources and to markets. Market access measured in terms of distance to urban markets for forest products and distance to the nearest tarred road were used to capture the impact of access to markets for forest products on household forest income. The amount of land cultivated and planted in hectares captures the household's opportunity cost of labour devoted to harvesting forest products, the availability of forest 
exit options, and household's food security situation.

Households collect forest products to meet their daily consumption needs and use and the surplus is sold in local and urban markets. Households who are more reliant on forests for subsistence use are expected to be more knowledgeable about the rural environment and about the occurrence of forest products in their area. In order to capture this minimum household consumption of forest products, their local knowledge of the rural environment and the importance of forest products, information on household subjective ranking of the importance of different forest products.

\section{Variables Definition and Hypothesis Dependence on the forest as a source of revenue}

In most developing economies where quite large number of population leads a scanty subsistence living, resources such as forests play a crucial role in the day to day living of this population. They depend on forests as a sole and/or alternative source of livelihood particularly in times of crop failure and slack seasons. In the case of AdabaDodola forest a statement coined by Tsegaye, 1999 states that “.....all people living inside and around the AdabaDododla forest practically satisfy the whole of their wood demands from the forest and for some the forest is a sole source of livelihood."

\section{Ranch Size}

Farming is not only the source of foodstuff for a rural household but also it is one of the most important sources of income to cover other requirements of a household. In the study area there is big difference in farm size among households. Usually those with larger farm size are relatively Poor than those with smaller farm size. Hence a respondent with larger farm size is high dependent on the forest as a source of income.

\section{Household composition}

The socio-demographic characteristics of households are essentially measures of a household's productive capacity which influence households' choices and preferences over use of different resources (Agrawal \& Angelsen, 2010). For example, studies carried out in Dodola areas clearly indicate that there is a strong positive correlation between household size and the consumption pattern of the wood-based products of community forestry (Shackleton et al, 2004). Thus, the demand for fuel-wood and most other forest products, for example, vary directly with household size and might influence preferences to manage forest resources.

\section{Ethnic homogeneity}

Although, the impacts of group size and heterogeneity on forest commons outcomes are uncertain (Agarwal, 2001), most resources are managed by groups divided along multiple dimensions, such as ethnicity, gender, religion, wealth and caste (Agrawal \& Angelsen, 2010). A large number of empirical studies suggest that similar group heterogeneities may produce different effects under different circumstances. However, characteristics such as gender, native status, ethnicity, class and income are particularly relevant to explain forest management outcomes. Different dimensions of social, political or economic heterogeneity can have different effects on resource governance (Maskey et al, 2006). There is a distinct relationship between ethnic homogeneity and social capital, mainly in trust and participation. Ethnically diverse communities are poor in social networks and low in participation. Individuals living in more racially fragmented societies participate less. Therefore, policy makers in CBO should pay attention to the dynamics of ethnic construct of the community, especially with respect to immigrants to the community (Maskey et al, 2006). Political and cultural differences within the community can also create problems among stakeholders, resulting in lack of interest to participate in forest management (Agrawal \& Angelsen, 2010).

\section{Gender}

The gender disparity in decision-making power within households harms the participation of women, thereby losing women's potential both in human resource and knowledge in CBO (Maskey et al, 2006). Women often participate for reasons including: responsibilities and expected behaviour, the rules governing the community forestry groups, social barriers stemming from cultural constructions of gender roles, logistical barriers relating to the timings and length of organizational meetings and male bias in the attitudes of those promoting community forestry initiatives (Mwangi et al, 2011).

Empirical studies on women's participation often cite the social context as one of the important factors affecting women's participation (Kalpana, 2009). Women endure to be trouble by insecure access and property rights to forest and tree resources, discrimination and male bias in the provision of services, including credit and technology, and exclusion from decision making at household, community and national levels. Moreover, because of lack of personal networks, formal education and employment, they are poorly placed to influence resource allocation or research priorities (Mwangi et al, 2011). The fact that women bear the main responsibility for 
childcare and housework, in addition to their share of agricultural work, cattle care, etc., means that they have high work burdens and logistical constraints. This seriously restricts women's ability to attend lengthy meetings held at inconvenient times (Agarwal, 2001).

\section{Dependent Variable and Expectation of Variable's Effects}

Forest Income 2009 E.C (QUANTS): It is a continuous variable which represents dependent variable; the income from forest for the household in the year 2009 E.C which is measured in ETB.

The Independent Variables: The following explanatory variables were hypothesized to influence the forest income in the study area.

\section{Household size}

This variable is a continuous explanatory variable and refers to the total number of family in the household that can be taken as a proxy for level of consumption and they engaged in different livelihood activities. From this context, family size is expected to have negative impact on collection of forest products. Family is the main source of labor in many rural areas and availability of family labor contributes to increase the collection of forest products (Mohammed, 2007). The larger the household size of the respondent, the higher was the likelihood of access to NTFPs (Coulibaly- lingani, 2009).

\section{Distance to the market}

It is a continuous variable and is measured in kilometres which farmers spend time to sell their product to the market. If the farmer is located in a village or distant from the market, he/she is easily accessible to the market. The closer to the market the lesser will be the transportation cost and time spent. Therefore, it is hypothesized that this variable is negatively related to marketable surplus of forest production. Distance to the market is one of the most important factors determining the profitability of extraction and marketing enterprises of NTFPs (Neumann and Hirsch, 2000).

\section{Education level of Households}

It is a continuous variable and is measured in using formal schooling the households and expected to have positive effect on forest resource income. Higher level of formal schooling is associated with less forest cutting (Contreras and Godoy, 2001). Higher level of education provides a wider range of employment opportunity and reduces forest dependency (kamanga et al, 2008; Adhikari et al, 2004; Shylajan and Mythili, 2007).

\section{Farming experience}

This variable shows the number of years a household practiced in farming and is a continuous variable. Experience in farming is expected to have positive relation with farm level. The variation which is large between the maximum and minimum years of experience shows that respondents have been actively engaged in forest products starting from an early age in the study district. When the farmers are more experienced they are familiar with every condition they face in production process and they can solve easily even the problems incur in their productions.

\section{Age}

It is a continuous variable and measured in years. This may be the fact that age is a proxy measure of production experience of household. Aged households are believed to be wise in resource use, and it is expected to have a positive effect on forest resource income. Households with in the most active age had a better change of access to NTFPs compared with older households (Lingani, 2009). And also Cavendish (2000) contradict this idea, and argued that older people have difficulty in carrying out arduous agricultural tasks and may turn to experience based resource collection activities that demand less physical labor.

Income from livestock: It is a continuous variable and expected to have negative effect on forest resource income. Poor groups depend on greatly on forest and forest product commodities than high-income or wealthy groups. Poor households are unable to allocate as high share of income to purchased foods compared to more livelihood income households. 
Table.5: Description of dependent variable and independent/explanatory variables

\begin{tabular}{lllll}
\hline Variables & Description of Variables & Category/types & Unit of measurement & Expected sign \\
\hline F income & Forest income & Continuous & ETB & + \\
Age & Age of household head & Continuous & Years & $+/-$ \\
H size & Family size of household head & Continuous & Head count & - \\
Educ. 1 & Education level of household & Continuous & Years of schooling & + \\
Gender & Sex of the household head & Dummy & $1=$ male 2=female & + \\
F. Exp. & Experience of household & Continuous & Years of experience & + \\
H E. & Employment level & Continuous & ETB & $+/-$ \\
IFLS & Income from live stock & Continuous & ETB & $+/-$ \\
& Income crop production & Continuous & ETB & $+/-$ \\
CPI & H level of participation & Dummy & Rank & + \\
HLPC & Motivation level & Dummy & Rank & - \\
MP & Institutional factor & Dummy & Rank & + \\
IF & REDD + & Dummy & Order & + \\
REDD & & & & \\
\hline SOurce & & & &
\end{tabular}

Source own data (2018)

\section{RESULTS AND DISCUSSIONS}

\section{Household Characteristics}

The average age of the respondents was 45years (Table 4). The average family size the interviewed households was 8 , which is higher than the national average of 5 persons per family. This discrepancy is probably caused by an inadequate difference of the view of "family" on the one hand and "household" on the other.

Table 6: Family structure

\begin{tabular}{llll}
\hline Socio-economic characteristics & Average & Maximum & Minimum \\
\hline Age (years) of the respondent (household head) & 45 & 90 & 24 \\
Family size (no of members) & 8.16 & 17 & 1 \\
Male household members & 4.2 & 10 & 1 \\
Female household members & 3.9 & 9 & 1 \\
\hline
\end{tabular}

Source: Survey data, 2018

According to the result of Table 5 above and Figure 3 below, more than half of the sample households were children under 15 years of age. Out of the 245 children aged 6 to 14 years only 100 (40.8\%) attended school. According to Todaro (1997) concept of "the hidden momentum of population growth," large proportion of children and adolescents in a population implies high dependency ratio in the present and large number of potential parents, which will inevitably put immense pressure on the forest resources in the future.

Meanwhile, on the FBAC document it is indicated that restricting settlements of the agreed number of homesteads in the WAJIB blocks is one of the votive duties of the WAJIB groups. In other words, the WAJIB members can't open new settlements in the forest other than those registered homesteads during settlement census. The high proportion of young generation in the WAJIB blocks and the prescribed duty of the WAJIB groups to restrict settlements will sooner or latter create tremendous internal pressure that risks the sustainability of the WAJIB approach unless something fundamental is designed.

Table7: The link between low educational level and high dependence on forest

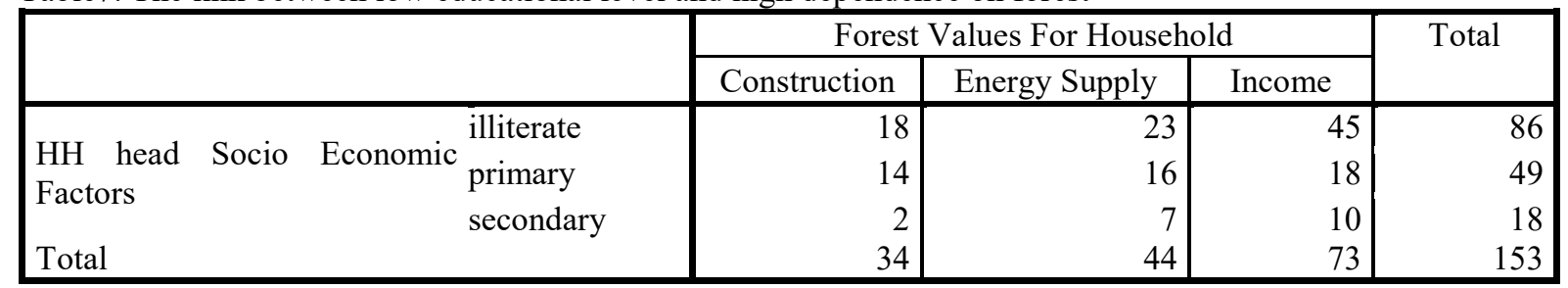

Source: Survey data, 2018

Figure 3. shows that nearly $57.3 \%$ of household members were illiterate and only $11.3 \%$ had more than primary education levels. So that the level of education also an impact on forest dependability. The study shows that illiterate $\mathrm{HH}$ members highly depend on forest than educated $\mathrm{HH}$ members. This is in line with study by Mustefa S and Teyiba A, 2017 (Table7.) As you observed from above table (7) there is a significant variation of forest use across educational status. 


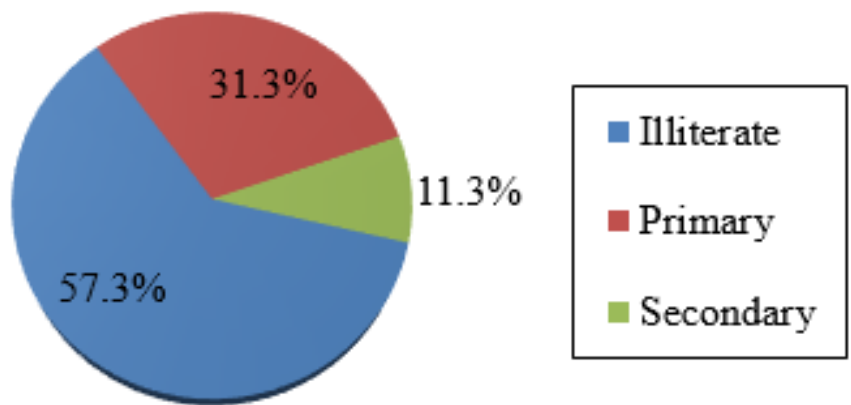

Figure 2 : Education levels of the interviewed heads households.

\section{Source of Households Income and Role of Forests for their Income}

\section{Crop production}

The result shows that the livelihood of people in the study area is based on agriculture (crop production and livestock production). The main types of crop production that produced last year in the study area were teff, wheat, barley, beans, pea and vegetables, fruits. The income of respondents from the crop production last year is presented in the table below.

Table 8: Income of households from crop production

\begin{tabular}{llllll}
\hline Variables & No & Min & Max & Mean & Std. Deviation \\
\hline Income from crop production & 153 & 0 & 32300.00 & 11048.39 & 5599.97 \\
Sales of crop production & 153 & 0 & 7000 & 1335.78 & 1340.45 \\
\hline
\end{tabular}

Source: Own survey (2018)

Table 8, shows that the income of households from crop production with average sales last year. The mean annual income from crop production in the study area is found to be about $11048.39 \mathrm{Br}$. The maximum income from crop production in the previous year was about $32300 \mathrm{Br}$. According to focus group discussions and individuals interviews the income generated from crop production in the study area were not cover yearly budget of households in all. Therefore, this is why because livelihood of households were depend on forest resource production.

\section{Livestock Production}

Table 5: Livestock production

\begin{tabular}{llllll}
\hline Livestock production & No & Minimum & Maximum & Mean & Std. Deviation \\
\hline Oxen & 153 & .00 & 8.00 & 1.8258 & 1.19059 \\
Cows & 153 & .00 & 9.00 & .9871 & 1.12231 \\
Heifer & 153 & .00 & 3.00 & .6645 & .74970 \\
Sheep & 153 & .00 & 17.00 & 2.4452 & 3.86819 \\
Goats & 153 & .00 & 10.00 & .3742 & 1.37769 \\
Donkeys & 153 & .00 & 7.00 & 1.0387 & .95946 \\
Horses & 153 & .00 & 2.00 & .2452 & .46069 \\
Poultry & 153 & .00 & 30.00 & 3.1548 & 4.33221 \\
Calves & 153 & .00 & 6.00 & .1948 & .62704 \\
\hline
\end{tabular}

Total sum) 153

Source: Own survey (2018)

The major livestock types commonly reared in the study area include oxen, cows, heifer, sheep, goats, donkeys, horses, poultry and calves. Among these, oxen are used for farming, donkeys for carrying, and sheep and poultry are mainly kept for marketing to generate income.

\section{Income from livestock production}

Table 10: Total income and Average sales from livestock products per year

\begin{tabular}{llllll}
\hline Variables & No & Minimum & Maximum & Mean & Std. Deviation \\
\hline Income from Livestock & 153 & 0 & 34000 & 4289.68 & 5234.71 \\
Sales of Livestock & 153 & 0 & 15000 & 997.16 & 1878.07 \\
\hline
\end{tabular}

Source: Own survey (2018)

Table 11 shows that income of households from livestock production and average sales last year. The mean annual income from livestock production in the study area is found to be about $4289.68 \mathrm{Br}$. The maximum income from livestock production in the previous year was about $34000 \mathrm{Br}$. According to focus group discussions and individuals interviews the income generated from livestock production like crop production in the study area were 
not cover yearly budget of households in all. Therefore, this is why because livelihood of households were depend on forest resource production.

\section{Forest Production}

Trees Ownership and Natural Forest

Table 11: Tree ownership and responsibilities of collecting

\begin{tabular}{llll}
\hline Variables & & Frequency & Percent \\
\hline Own trees/forest & Yes & 62 & 39.7 \\
\multicolumn{1}{c}{ Total } & No & 93 & 60.3 \\
& & 155 & 100 \\
\hline Responsible for collecting FP & Men & 30 & 19.2 \\
& Women & 95 & 61.6 \\
Total & Children & 30 & 19.2 \\
& & 155 & 100 \\
\hline Reason for harvest FP & for home use & 99 & 63.5 \\
& for sale & 13 & 8.3 \\
\multicolumn{1}{c}{ Total } & both & 43 & 28.2 \\
& & 155 & 100 \\
\hline
\end{tabular}

Source: Own survey (2018)

The above result implies that more than half percent of the sample households depends on natural forest or public forest. Those households who do not have their own trees depends largely on natural forest than those who have their own trees. Moreover, findings under table 14 shows that the responsible for collecting and selling of forest products in the study area were majority undertaken by for women 134(85.9\%) than men's and children's. The major reason for cutting trees were for own subsistence use for cooking 99(63.5\%), for sale 13(8.3\%) and for both home use and sale 43(28.25). From this, we understand that the major reason for cutting trees and harvesting a forest is for home use rather than selling.

Types of forest used by households and ways of selling

Table 6: types of forest do households get the most important

\begin{tabular}{llll}
\hline Variables & & Frequency & Percent \\
\hline Types forest & Natural forest & 88 & 56.32 \\
& Plantations forest(public) & 30 & 20 \\
& Own woodlots & 36 & 23.7 \\
\hline Way of selling & Total & 153 & 100 \\
& market based & 61 & 39.1 \\
& seasoning & 59 & 37.8 \\
& illegally & 24 & 15.4 \\
& legally & 11 & 7.7 \\
\hline
\end{tabular}

Source: Own survey (2018)

The result shows that more than half $56 \%$ of interviewed households were rely on the natural forest while around $44 \%$ of them were on plantations and own woodlots. This implies that majority of livelihood of households in the study areas were depended on natural forest than plantations and own woodlots.

Total Forest Income

Table 13: total income and Annual average income from selling forest products

\begin{tabular}{lccccc}
\hline Variables & No & Minimum & Maximum & Mean & Std. Deviation \\
\hline Income from forest products & 155 & 600 & 25000 & 9486.77 & 4311.89 \\
Sales of forest products & 155 & 0.00 & 10000 & 2720.97 & 1953.33 \\
\hline
\end{tabular}

Source: Own survey (2018)

The mean annual income from forest production in the study area is found to be about $9486.77 \mathrm{Br}$. The maximum income from forest production in the previous year was about $25000 \mathrm{Br}$. According to focus group discussions and individuals interviews the income generated from forest production play great role in fulfilling to cover yearly budget of households in the study area. 


\section{Income from non-farm resources}

Table 13. Household income from Non-farm sources (only 56 valid)

\begin{tabular}{llllll}
\hline & $\mathrm{N}$ & \multicolumn{2}{l}{ Minimum Maximum Mean } & Std. Deviation \\
\hline land renting & 155 & .00 & 5000.00 & 65.16 & 443.80 \\
daily labor & 155 & .00 & 36000.00 & 1072.00 & 3914.97 \\
food aid & 155 & .00 & 600.00 & 3.87 & 48.19 \\
Petty trade (selling local beer, katicala, food, shopping) & 155 & .00 & 15000.00 & 896.39 & 2105.63 \\
Others such as carpentry, pottery, civil services & 155 & .00 & 12000.00 & 189.35 & 1128.022 \\
Valid N (list wise) & 56 & & & \\
\hline Total income from non-farm & 155.00 & 36000.00 & 2140.00004330 .03284 \\
\hline
\end{tabular}

Total income from non-farm

Results (table 23) shows that out of 155 respondents, only 56 of them were valid and they respond that the non-farm resources which they generated income from were land renting, daily labor, petty trade, food aid and others such as (carpentry, pottery, civil services). From this, the mean total income from non-farm resource was $2140.00 \mathrm{ETB}$ and standard deviation is 4330.03ETB

Table14: Forest income contribution the interviewed household obtained in 2017 of WAJIB

\begin{tabular}{|c|c|c|c|c|c|c|}
\hline \multirow{2}{*}{\multicolumn{3}{|c|}{ Income distribution of $\mathrm{HH}$}} & \multicolumn{3}{|c|}{ Family size of $\mathrm{HH}$} & \multirow[t]{2}{*}{ Total } \\
\hline & & & less than 5 & $6-10$ & greater than 11 & \\
\hline \multirow[t]{5}{*}{ Construction } & HHIS in 2017 & $<1 \mathrm{oK}$ & 1 & 2 & 6 & 9 \\
\hline & & $10 \mathrm{~K}$ to $<30 \mathrm{~K}$ & 4 & 4 & 12 & 19 \\
\hline & & $30 \mathrm{~K}$ to $<60 \mathrm{k}$ & 0 & 1 & 1 & 2 \\
\hline & & $>=60 \mathrm{~K}$ & 0 & 0 & 0 & 0 \\
\hline & & Total & 5 & 7 & 21 & 33 \\
\hline \multirow[t]{5}{*}{ Energy Supply } & HH IS in 2017 & $<10 \mathrm{~K}$ & 1 & 2 & 4 & 7 \\
\hline & & $10 \mathrm{~K}$ to $<30 \mathrm{~K}$ & 1 & 0 & 6 & 7 \\
\hline & & $30 \mathrm{~K}$ to $<60 \mathrm{~K}$ & 4 & 14 & 18 & 36 \\
\hline & & $>=60 \mathrm{~K}$ & 0 & 0 & 0 & 0 \\
\hline & & Total & 6 & 16 & 28 & 44 \\
\hline \multirow[t]{5}{*}{ Income } & HHIS in 2017 & $<10 \mathrm{~K}$ & 16 & 23 & 27 & 66 \\
\hline & & $10 \mathrm{~K}$ to $<30 \mathrm{~K}$ & 0 & 2 & 3 & 5 \\
\hline & & $30 \mathrm{~K}$ to $<60 \mathrm{~K}$ & 0 & 1 & 2 & 3 \\
\hline & & $>=60 \mathrm{~K}$ & 0 & 0 & 0 & 0 \\
\hline & Total & & 16 & 26 & 31 & 73 \\
\hline
\end{tabular}

Source: Survey data, 2018

The study shows the proportion of income generation in the WAJIB blocks and the dependability of the WAJIB groups are too high in forest to earn income (Table8). This means that household who have a large family size is highly depend on forest than the household who have small family size. Obviously households using /obtain different benefit but the category of construction, energy supply and income contribution is based on the household survey.

\section{Dependence on the Forest}

The WAJIB groups who used to depend on the forest for various purposes are still depending on the same mainly for grazing, firewood and construction materials even after WAJIB members formed (Mustefa Sultan, 2017). However, members are used the results of forest by astute manner. This may vividly decreases the importance of the forest resources in the contributing income of the people and the fact that they have remaining access to forest where the WAJIB approach has not yet reached. 
Table 15: Major forest values reported by the interviewed households In WAJIB

\section{Forest Values For Household}

\begin{tabular}{|ll|r|r|r|r|}
\hline & & & & \multicolumn{1}{c|}{$\begin{array}{c}\text { Cumulative } \\
\text { Percent }\end{array}$} \\
\hline Valid & Construction & 33 & 22.0 & 22.0 & 22.0 \\
& Energy Supply & 44 & 29.3 & 29.3 & 51.3 \\
& Income & 73 & 48.7 & 48.7 & 100.0 \\
& Total & 150 & 100.0 & 100.0 & \\
\hline
\end{tabular}

Source: Survey data, 2018

The major forest products reported by households include firewood, poles, timber (planks), wood splits, charcoal, logs, tree branches, wooden tools and medicinal plants. However, $73 \%$ of total forest income comes from firewood (energy supply) 44\% and construction (33\%) (Table8). In terms of relative income, firewood or energy supply is the most important forest product for all households although it is more important to the lower income groups. Whereas products such as construction materials and poles, which can often be obtained from dead and dying trees, are the most frequently used products by all income classes, timber appears to be more accessible by fewer, improved rotten households. Production of timber and poles is mainly to generate cash income.

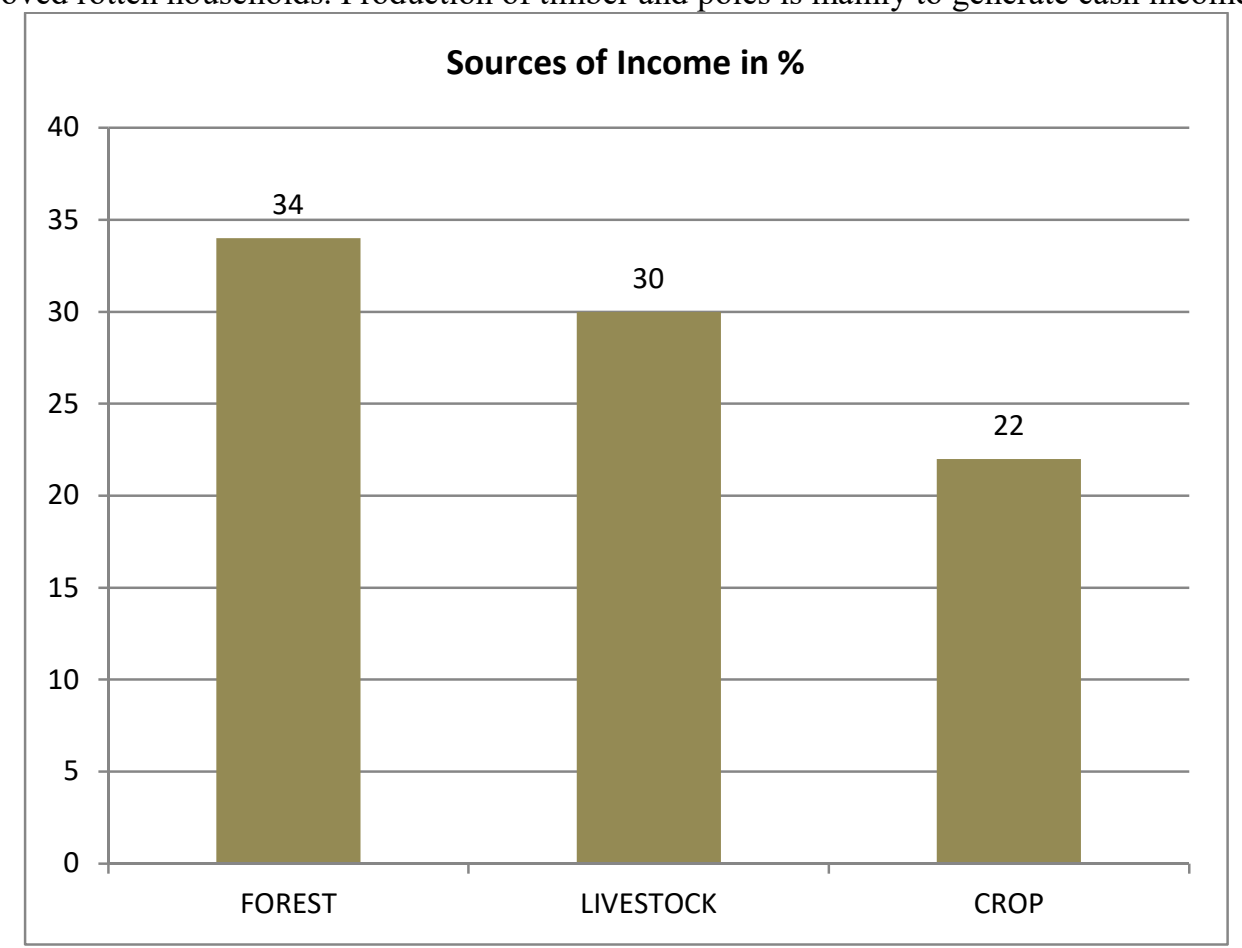

Source: Survey data, 2018

Figure 4: Contribution of forest per capital income

Forest income helps many households from falling under the poverty level. If forest income is omitted, the occurrence of poverty would rise. Regardless of income level, forest income is an important source of cash income and contributes substantially to financial expenses in crop and livestock production. Study shows that households on average earn $51.3 \%$ of their cash income from forest products. The main sources of income are crop production, livestock production, and extraction of forest and environmental products. The result shows that forest products constitute an important part of the household income portfolio contributing $34 \%$ of total per capita income followed by livestock (30\%), crop (22\%), and environmental products (6\%). Private business, remittance, transfers, and wage together constitute only $6 \%$ of total per capita income (Figure4). If forest income which usually is not fully accounted for in the national account estimate is excluded the poverty incidence will rise.

In terms of relative income, firewood is the most important forest product for all households although it is more important to the lower income groups. Whereas products such as firewood and poles, which can often be obtained from dead and dying trees, are the most frequently used products by all income classes, timber appears to be more accessible by fewer, better off households. Production of timber and poles is mainly to generate cash income. The results show the important role that forest income plays in alleviating poverty and in reducing 
vulnerability to shocks. Forest income is also one of the main sources of cash income, improving the financial capabilities of households, particularly among the poorer households. The link between alleviation of poverty and forest management is clearly indicated which also implies the importance of sustainable forest management for peoples livelihoods and, thus, the potential for involving the users themselves in the planning and management of the forest resource. Higher income households employ more capital-intensive production in the form of a higher use of inputs such as fertilizer, hired labor, rented land and harvesting machines. When forest income is considered, households in the top quintile income class earn four times as much forest income as the lowest income class whereas their dependence on forest income (ratio of forest income to total income) is less than half of the lowest quintile class. Dependence on the forest also decreases with area of cropland and number of large livestock and increases with the distance from the town. According to the respondent idea in the WAJIB group the forest contribution based on the value are ranking as ascending order are looks like, Income, fire wood, or energy supply, construction materials, grazing, and pole respectively. The study shows that the CBOs are still depending on the forest as a source of revenue but in the form of sustainable ways. The survey result carefully, WAJIB members of households have continued to depend on the forest resources to earn maximum income from forest. The study can be seen that forest dwellers were using firewood for home consumption and sale in the WAJIB members with sustain manner. On the other hand, construction material is almost equally used for home consumption and sale by the forest dwellers in WAJIB. From Table 9 shows the degree to which the respondents depend on marketable wood products such as firewood, construction materials and charcoal, in the WAJIB. It is revealed that $73 \%$ forest dwellers depend on these products as a source of revenue in the WAJIB.

Indeed, the role of the income from the forest would be higher if other direct and indirect incomes from the forests are considered.

The study shows that the amount of the financial benefit of forest income contribution in each WAJIB groups or categorise from $<10 \mathrm{~K}, 10$ to $30 \mathrm{~K},>30 \mathrm{~K}$ to $60 \mathrm{~K} 2009 / 2017$ year. Those categorise was done by the researcher (Table 8).

Table 16: Forest Income contribution in the WAJIB members in 2009/2017

\begin{tabular}{|c|c|c|c|c|}
\hline \multirow{2}{*}{ WAJIB members } & \multicolumn{4}{|c|}{ Financial Benefit } \\
\hline & $<10 \mathrm{~K}$ & 10 to $30 \mathrm{~K}$ & $>30 \mathrm{~K}$ to $60 \mathrm{~K}$ & Total \\
\hline Ali & 5 & 2 & 0 & 7 \\
\hline Anunu Lobe & 7 & 0 & 0 & 7 \\
\hline Artu Fite & 5 & 2 & 0 & 7 \\
\hline Birbirsa Guta & 8 & 0 & 0 & 8 \\
\hline Botole Changiti & 7 & 0 & 0 & 7 \\
\hline Bulchano & 7 & 0 & 0 & 7 \\
\hline Bulchano H & 5 & 2 & 0 & 7 \\
\hline Changiti & 6 & 1 & 0 & 7 \\
\hline Deneba Hida Tula & 5 & 2 & 0 & 7 \\
\hline Gede & 7 & 0 & 0 & 7 \\
\hline Ido Sibilo & 5 & 3 & 0 & 8 \\
\hline Ido Wite & 4 & 3 & 0 & 7 \\
\hline Jeldo Bubisa & 6 & 1 & 0 & 7 \\
\hline Lephepho Dugda Guda & 8 & 0 & 0 & 8 \\
\hline Lobe Gutu & 5 & 3 & 0 & 8 \\
\hline Mudi & 6 & 0 & 0 & 6 \\
\hline Sadi Oda & 7 & 0 & 0 & 7 \\
\hline Sakora & 6 & 0 & 0 & 6 \\
\hline Shushi Shika & 8 & 0 & 0 & 8 \\
\hline Sulula & 6 & 0 & 0 & 6 \\
\hline Tarura & 5 & 2 & 1 & 8 \\
\hline Total & 130 & 22 & 1 & 153 \\
\hline
\end{tabular}


Table 17: Descriptive distribution of forest Income contribution in the WAJIB members

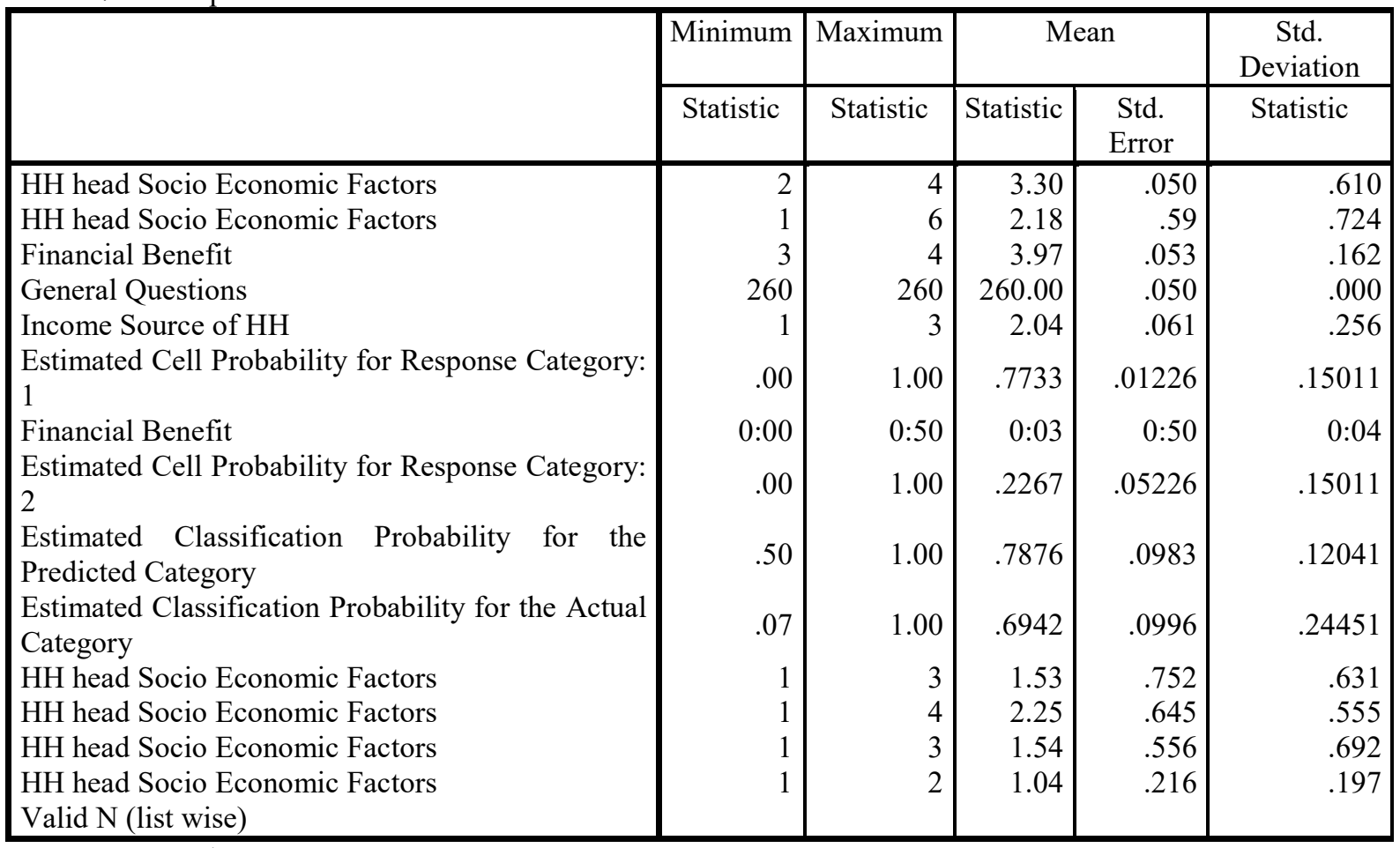

Source: Survey data, 2018

Based on the dominant component loadings, the first CBO shows that households that attached high values on Firewood (energy supply) also attached high values on construction materials and on the fact that forests are reservation or sacred place. The majority of the values, except preserve, are all associated with the utilization of forests for products and services that satisfy human wants and needs. The results indicate that the households attached their most important values to forests by interpreting and regarding the forest in terms of human-centred values and experiences.

\section{Determinants of Households' Income from Forest Resource}

In this section, the factors that influence the income from forest resource in the study area are presented and discussed. Various variables which expected to influence forest income were included Age, Gender, Household size, HH employment level, Income from livestock, crop production income, HH level of participation, motivation for participation, Institutional Factors, REDD+ contribution for PFM. Multiple linear regression models were employed to analysis the factors that determine forest contribution for the household economy. Before estimating the parameters multi-collinearity tests was performed using, variance inflation factors (VIF) for multi-collinearity. Test for Multi-collinearity: Variance Inflation Factor (VIF) was employed to test the existence of multi-collinearity problems among continuous explanatory variables and dummy variables. The result for all VIF ranges between 0.152 and 1.766 . Regarding the multi-collinearity problems among the continuous explanatory variables, the test result shows all the VIF values were less than 10 . Thus, there was no serious multi-collinearity problem among continuous independent variables (see Annex 3).

The goodness of the models: The overall goodness of fit of the regression model is measured by the coefficient of determination $\left(\mathrm{R}^{2}\right)$. It tells what proportion of the variation in the dependent variable, or regress and, is explained by the explanatory variable. $\mathrm{R}^{2}$ lies between 0 and 1 , the closer it is to 1 and the better is the fit. The coefficient of multiple determinations $\left(\mathrm{R}^{2}\right)$ was estimated 0.242 and adjusted $\mathrm{R}^{2}$ value was 0.176 . This means that $24.2 \%$ of the variation in the dependent variable is explained by the explanatory variables included in the model and rest determined by error terms.

\section{Determinants of households' income from the forest}

In this subsection, the determinants of households' income from the forest are presented and discussed. The econometric result (table 11) shows that among the ten (10) hypothesized determinants of households income from the forest, six (5) variables were found significant. These are Age, Household size, Income from livestock, High level of participation and Institutional factors. 
Table.18: Linear regression analysis in the WAJIB avers all score.

\begin{tabular}{|c|c|c|c|c|c|}
\hline \multirow{2}{*}{$\begin{array}{l}\text { Dependent Variable: Forrest income } \\
\text { Predictor }\end{array}$} & \multicolumn{2}{|c|}{$\begin{array}{l}\text { Unstandardized } \\
\text { Coefficients }\end{array}$} & \multirow{2}{*}{$\begin{array}{c}\text { Standardized } \\
\text { Coefficients } \\
\text { Beta }\end{array}$} & \multirow[b]{2}{*}{$\mathrm{t}$} & \multirow[b]{2}{*}{ Sig. } \\
\hline & $\mathrm{B}$ & Std. Error & & & \\
\hline (Constant) & 1.434 & .468 & & 3.061 & $.003 *$ \\
\hline Age & -.113 & .055 & -.159 & -2.072 & $.040^{*}$ \\
\hline Gender & .028 & .102 & .027 & .276 & .783 \\
\hline Household size & .095 & .052 & .157 & 1.832 & $.069^{*}$ \\
\hline HH employment level & -.092 & .204 & -.034 & -.451 & .652 \\
\hline Income from livestock & .246 & .084 & .232 & 2.922 & $.004 * *$ \\
\hline Income from crop production & -.101 & .096 & -.080 & -1.051 & .295 \\
\hline HH level of participation & .366 & .099 & .297 & 3.705 & $.000 * * *$ \\
\hline motivation for participation & -.035 & .064 & -.042 & -.540 & .590 \\
\hline Institutional Factors & -.139 & .079 & -.136 & -1.765 & $.080^{*}$ \\
\hline REDD + contribution for PFM & -.058 & .088 & -.052 & -.654 & .514 \\
\hline
\end{tabular}

$\begin{array}{lc}\mathrm{R}^{2} & 0.242 \\ \text { Adjusted } \mathrm{R}^{2} & 0.176\end{array}$

Source: Survey data, 2018,

$*, * * * * *$ indicates significance level at $10 \%, 5 \%$ and $1 \%$ respectively

Age: The result shows that age was significantly and negatively affected forest product at $10 \%$ level. An increase in one unit age indicated an increase in the forest products by 0.40 , other variables being constant.

Additionally Cavendish (2000) contradict this idea, and argued that older people have difficulty in carrying out arduous agricultural tasks and may turn to experience based resource collection activities that demand less physical labour.

Housed size: The result shows that family size was significantly and positively affected forest product at $10 \%$ level. An increase in one unit family members indicated an increase in the forest products by 0.69 , other variables being constant. This can be because of the fact that if the family number increases some might in forest production while others family members might have involved themselves in other alternative activities, which could be alternative sources of income. From this, it can be noted that less participation of family members in the production which in turn decrease the market supply of the products. Household size is the main source of labor in many rural areas and availability of family labor contributes to increase the collection of forest products (Mohammed, 2007). The result is in line with (Coulibaly- lingani, 2009). The larger the household size of the respondent, the higher was the likelihood of access to forest

Income from livestock: The study shows that income from livestock was significant and positively affected forest income $10 \%$ level. An increase in one unit income from livestock in forest product decreases by 0.004 .

Household head level of participation was positively significant at $1 \%$ and Institutional factors negatively and significant affect forest income by $10 \%$.

Finding so few variables to be significant in the all variables model raises the question whether simple significant relations between the dependent and explanatory variables become suppressed due to correlations between the explanatory variables. To shed some light on this it was analysed whether significant simple relations do exist between the dependent and independent variables. The chi-squared test of independence of categorical variables is used to determine whether the effects of one variable depend on the value of another variable (Sharp, 1979). In this study, it was used to test if the participation status of each household depended on the household head's Age, Household size, Income from livestock, HH level of participation and Institutional Factors.

\section{CONCLUSIONS AND RECOMMENDATIONS \\ Conclusion}

Forest resources are vigorous but diminishing in terms of obtainability and variety due mainly to human factors and natural factors. The effort of IFMP to congestion the Deneba and Berisa WAJIB is outstanding in that it rights forest dwellers with exclusive use rights in order to regulate uncontrolled access to the forest and to provide a maintainable solution to the "fatherless" state of the forest. This importance comes at the expense of the clear social cost of increases income mainly to the members of $\mathrm{CBO}$ in different ways.

Results of the study have exposed that there is a high perception of REDD+ in the WAJIB occurring mainly between the state forest conservation agencies and the community. After the implementation of WAJIB, there is sustainable access of forest in the WAJIB groups have become prominent by emerging into "controllable" catastrophes. Additionally the result depicts that the forest is the major income contributor to the household's than most of the household livelihood activities. The household earns $51.3 \%$ of cash income and $34 \%$ of total income 
from the forest for which they are provided with all rights to manage, develop and use.

A modifying factor is to be seen in the fact that in CBO members there is no equal or fair distribution of to derive income from the natural forest irrespective of family size to the WAJIB-scheme. On the other hand, forest dwellers too have to make sacrifices. Sustainable forest management necessarily yields less than overexploitation in the short run. Thus, it was to be probable that total sales of forest products decline due to WAJIB-implementation. In fact, this is what they should if the resource base is to be secured.

The regression test of significance of the relationship between Educational level and forest income products as a source of revenue and wealth status was found significant at more than $6 \%$ level of significance in WAJIB. It reveals the presence of relationship between the household's wealth status and dependence on the forest as a source of revenue in CBO. As the result shows the poorer, a household is the larger is its dependence on the forest as source of revenue. Therefore, the amount of cost of forest management starts from thinning to the annual membership fee that a member household has to pay for the general investigation.

According to the respondent in the WAJIB members in the study areas estimation of forest cost management needs 19,925 birr per ha up to the forest can give the actual function. The study can identify the amount of cost forest management from respondent what mentioned. Here I recommend that both government and NGOs can financially support households in the WAJIB members because the cost of forest management is high and difficult to cover only the farmers.

Households that attach more values on the products and services provided by forests are more motivated to invest their time in forest conservation activities. Thus, the values that households attach to forests disclose the degree of commitment they may have in conserving forests through local participation. Households can participate for anthropocentric, cultural/moral/spiritual and livelihood reasons and not just financial gains. Therefore, people's decisions to participate in WAJIB are verbalized by their magnetism to varied values, rather than through separate assessments of the costs and benefits of each part. By understanding the forest values that people hold, policy makers will be better equipped to design policies that reduce economic gaps with family size among stakeholders, and assist communities to implement forest plans.

Household decision to participate also depends on many socio-economic factors and the institutional setting in the management of local forests. In Deneba and Berisa, men are more probable to participate than women are because the gender disparity in decision-making power within communities that undermines the participation of women is here. In addition to women, older household heads, larger households, those who observe that there is degradation in the area and those who attach high anthropocentric and cultural/moral/spiritual values to forest resources are more likely to participate in $\mathrm{CBO}$. On the other hand, younger household heads, men, married people, those with high levels of household income or social grants are less likely to participate in CBO. Although households might have an interest to participate, they may in fact fail to do so if they are displeased with the way previous $\mathrm{CBO}$ initiatives have been managed i.e., $\mathrm{CBO}$ conflicts, perception of discrimination, running of the committees and if they do not have confidence in the continuity of benefits and benefit distribution.

\section{Policy Recommendations}

Drawing from the empirical results, this study recommends that:

$\checkmark$ Policy makers should consider the values households assign to forest resources not just financial benefits when authorizing policies to adoptive participation in the WAJIB.

$\checkmark \quad$ Forest products contribute large share of local community incomes in the study area. Therefore, conservation of forests is thus very essential to sustain local people livelihoods.

$\checkmark$ Development activities of Government extension services and Non-Governmental Organisations need to hold WAJIB and provide support to improve environmental and technical awareness. This can improve the perception of WAJIB members towards forest degradation and broaden the participation base and assurance the sustainability of WAJIB programs.

\section{Recommendations for Further Studies}

$\checkmark$ The levels of participation in WAJIB were not considered in this study. There is, therefore, a need for further examination on the factors influencing the different levels of household participation in a given WAJIB members (Motivation level in participation).

\section{ACKNOWLEDGEMENTS}

I would like to take the first opportunity to thank the almighty God for all his mysterious help and support given to me since my birth until today. Next, I want to confess that I never do anything utterly by myself; many people contributed their knowledge and ideas to my dissertation. I would like to take this opportunity to thanks them. In particular, I would extremely appreciate my advisor Yoseph Melka (Ph.D) for his keen, unlimited support and guidance from proposal development stage to final thesis preparation. I would like also to thank him for suggesting and providing me very important reading materials. 
I would also thank my beloved wife s/r Betelihem Abiyo for her patience, support and encouragement when I needed it most. Her presence in my life has given me great joy and has kept my sprit aloft even during times of mental and physical stress.

I would also like to thanks all my families, and friends as well as staff members of Wondo Genet College of Forestry and Natural Resources and friends for their respective unreserved material and non-material supports to me while preparing this thesis.

\section{REFERANCE}

Agarwal B (2001). Participatory exclusions, community forestry, and gender: An analysis for South Asia and a conceptual framework. World development 29 (10): 1623-1648.

Agrawal, A and Angelsen A (2010). Using community forest management to achieve. REDD+ goals in Realizing REDD: National... sitemaker.umich.edu/ifri/fles/ifri_may_2010_newsletter. pdf. (Accessed 22 June 2011).

Chomitz and Kumari, (1998). Empirical Regularities in the Poverty-Environment Relationship of African Rural Households. The Centre for the Study of African Economies Working Paper Series. Working Paper 105.

FAO (2006). State of the World's Forests 2006. Rome, FAO

FAO (2008). State of the World's Forests 2008. Rome, FAO

Haile Mariam et al., 2015. Non-carbon benefits for effective implementation of REDD+: The case of Bale Mountains Eco-Region, Southeastern Ethiopia Littlefield.

IFMP,(1999). Project Synopsis. Integrated Forest Management Project Adaba-Dodola (IFMP), Dodola, Ethiopia. (Unpublished project document).

Mustefa S. (2017). Contributions of Protected Area for Local Community Livelihood: The Case of Senkele Swayne's Hartebeest Sanctuary, South Eastern Ethiopia. Journal of Natural Sciences Research. Vol.7 (9)

Mustefa S. and Teyiba A, 2017. Assessment of anthropogenic factors affecting protected area: the case of Senkele Swayne's Hartebeest Sanctuary, South Eastern Ethiopia. International Journal of Current Research Vol 9 (01), PP45513-45521.

Oromia Forest and Wildlife Enterprise (OFWE), Farm Africa and SOS Sahel Ethiopia,2014. Bale Mountains Ecoregion Reduction of Emission from Deforestation and Forest Degradation (REDD+) Project ETHIOPIA

Tesfaye Y ,(2011) Forest Incomes and Poverty Alleviation Under Participatory Forest Management in the Bale Highlands, Southern Ethiopia.

Teshome, T. (1999). Effects of Grazing and Fire on Tree Regeneration in Coniferous Montane Forest of Dodola Area, Ethiopia. An MSc Thesis Presented to Gottingen University, Germany.

UNFCCC, 2013. Devloution and Community-Based Natural Resource Management: Creating Space for Local People to Particpate and Benefit? ODI Natural Resource Perspectives, №. 76.

Williams, M. (2002). Deforesting the Earth: From Prehistory to Global Crisis. University of Chicago Press. .

World Bank, (2011). Property Rights, Public Goods and the Environment, in: K-G. Maler and J.R.Vincent. Handbook of Environmental Economics, Vol. 2 